\title{
Trade and economic relations between Georgia and the Czech Republic: challenges in export and import of agri-food products
}

\author{
Badri Gechbaia ${ }^{1}$, Eteri Kharaishvili $^{2}$, Ekaterine Zviadadze $^{3}$, Zurab Mushkudiani $^{1}$, and Amiran Tsilosani $^{1}$ \\ ${ }^{1}$ Batumi Shota Rustaveli State University, Georgia \\ ${ }^{2}$ Ivane Javakhishvili Tbilisi State University, Georgia \\ ${ }^{3}$ Ministry of Environmental Protection and Agriculture of Georgia, Georgia
}

\begin{abstract}
The article evaluates the importance of trade and economic relations between countries in economic growth. At a time of globalization has been identified the existing problems of the international division of labor for Georgia. Substantiated that the development of trade and economic relations is an important challenge in the condition of a low level of food provision for the population of Georgia. From this perspective, it is relevant to analyse the export-import of agriproducts with those European countries that have similar resource potential, geographic proximity, socio-economic and political characteristics to Georgia, among of which is the Czech Republic. Based on the theories of international trade, in order to assess the trade and economic potential between Georgia and the Czech Republic and to determine trends of development, has been studied main indicators of the above-mentioned countries. Comparative analysis of the data showed that quantitative indexes are similar between these two countries, while the qualitative data in the Czech Republic is higher as compared to Georgia. The paper discusses the agriculture of Georgia as one of the main sources of economic growth, therefore, to increase the resource potential of the sector needs to develop foreign trade and economic relations with the agriproducts. Based on analysis of data on exportimport of agriproducts between Georgia and the Czech Republic, has been concluded that the trade balance between the countries is variable and trade and economic relations are at the development stage. The main challenge in agriproduct trade between the countries is a low level of import-export diversification of agriproducts. At the same time, it is substantiated, that the cooperation with the Czech Republic perspective for Georgia not only in trade but also in the sphere of investments and modern technologies. The article argues the need for an optimal ratio of exports and imports in the development of trade and economic relations. Through the empirical studies the current challenges of export and import of agri-food products between Georgia and the Czech Republic have been identified; export-import ratios have been analysed by product type; and the ways to improve trade and economic cooperation between the two countries have been outlined. Promising areas of economic relations and export-import between Georgia and the Czech Republic have been developed.
\end{abstract}

\section{Problem statement}

Today, almost every country in the world is involved in the international division of labour; otherwise it would be impossible for a country to provide its own population with agri-food products. An important challenge for any country is the development of trade and economic relations. However, it should be borne in mind that in the context of the international division of labour, a country always needs to import resources, consumer goods and services, and the main source of covering import costs should be export earnings. Export earnings are the main sources for covering import costs in order to maintain the food security [1].

Nowadays, the development of trade and economic relations between the countries is taking place against the background of irreversible globalization processes, which has a certain impact on the modernization of the political and economic environment of Georgia. In view of the above, it is necessary to take into account the experience of economic and political transformation of the leading industrialized countries.

\section{Research methods}

In the process of research has been used various methods of research, particularly:

Based on bibliographic and empirical research has been analyzed scientific papers of Georgian and foreign researchers, publications of the National Statistics Office of Georgia, Policy documents of the Parliament of Georgia, analytical reports, etc.;

Based on comparative method has been determined similarities and differences between Georgia and the Czech Republic in terms of social and economic and other indexes;

\footnotetext{
* Corresponding author: gechbaia.badri@bsu.edu.ge
} 
Analysis, synthesis, induction, and other methods allowed to select and group the data, identify the trends, similarities, and differences;

Based on statistical methods has been calculated average export and other indexes of agriproducts;

Based on the grouping method has been determined export material groups by Georgia and the Czech Republic;

- Based on interviews with the experts of the agriproduct sphere has been assessed and refined quantitative and qualitative indexes;

Based on the household research database has been defined the order between analytical and statistical assessments;

Based on the household research database, statistical data, materials of the Ministry of Environmental Protection and Agriculture of Georgia, data from ministries of economic profile has been defined the order between analytical and statistical assessments.

\section{Background}

Production of agro-food products in Georgia is a traditional field; however, a particularly difficult social background among economic problems is related to food security, rising food prices, inflation, negative trade balance between exports and imports of agri-food products [2]. Self-sufficiency in local agri-food products in Georgia is low. According to the data for 2018, the selfsufficiency ratio in wheat is especially low $-15 \%$, corn $71 \%$, vegetables $-59 \%$, potatoes $-102 \%$, grapes $-152 \%$, meat $-52 \%$ (beef $-77 \%$, pork $-45 \%$, poultry $-34 \%$ ), eggs $-99 \%$, milk and dairy products $-81 \%$ [3].

In Georgia, the share of food exports in total exports is low. This figure averaged $9 \%$ in 2018 . For the first three quarters of 2019 , the same indicator is $7.5 \%$, which is lower than the corresponding indicator for the previous year [3].

In Georgia, the share of household spending on food in total consumer spending is high. In 2018, this figure was $42 \%$ [3]. Also, a comparative analysis of the recent data revealed that price indexes of food and non-alcoholic beverage are on the upward trend. Prices for most of the food products also went up [3]. As of 2018, the share of household monetary income from the sale of agricultural products was $5.5 \%$, while in 2015 this indicator was $7.1 \%$. Average monthly income also decreased - from GEL 68.5 (2015) to GEL 57.4 (2018) [3]. The poverty rate remains high in the country. The share of the population below the absolute poverty line was $21.9 \%$ in 2018 [3].

One of the important factors for improving the economic situation in Georgia and achieving food security is to search for the ways to increase export potential and develop trade and economic relations, especially with European countries. Development of trade and economic relations between Georgia and the leading countries of the world, including ensuring the optimal balance of exports and imports, will have a positive impact on the political and social situation of the countries, especially on the welfare of their population. In this regard, it is promising to share the experience of successful countries and identify opportunities for the development of trade and economic relations between countries. As noted above, it is especially important for Georgia to share European experience and identify current problems of export and import of agri-food products with a country with similar economic and political characteristics, as well as determine the prospects for the export potential of these products. The Czech Republic is included in the list of such countries; therefore the purpose of the study is to identify problems in the export and import of agri-food products between the two countries based on the study of trade and economic relations between Georgia and the Czech Republic and make recommendations on development prospects.

\section{Data and empirical analysis}

Comparison, analysis, induction and other methods have been used in the research process. The export potential has been estimated using the respective models by commodity groups and by the countries (Georgia and the Czech Republic).

Georgia belongs to a number of small countries. A study by A. Smith [4] identified the importance of the size of a country for its economic development. Countries with large areas, due to the great potential of diverse climatic and natural resources are more capable to secure their own economic self-sufficiency than small ones. According to the same theory, a country should manufacture the goods production of which will cost less compared to other countries, and import the goods production costs of which are higher [4]. D. Ricardo's theory, according to which all countries can benefit from international trade due to differences in production costs, should also be considered. According to David Ricardo, personal interests merge with public interests, and exchange turns all nations / states of the civilized world into one universal society. The arguments put forward are to some extent the basis of the modern theory of trade, and therefore they are so interesting today, even in the conditions of the global economy [5].

The role of trade and economic relations between countries is important to enhance economic efficiency. However, when developing foreign economic relations, it is necessary to take into account not only the costs of export and import, but also the consumer properties of the products purchased. In addition, it is necessary to compare the level of labour costs to the production costs of the exported product with that can be replaced by import.

Export promotion and import substitution [6] are considered as an alternative to the development of international trade and the choice between them depends on the level of development of countries [7], their natural resource potential, the demand and supply situation, the level of development of food markets [8].

The export structure of a country depends largely on the demand in the importing countries. First of all, for the export of products it is necessary to saturate the domestic market, and for the successful sale of the product the structure of demand should be similar to the structure of demand in the exporting country [9]. Modern approaches 
to international trade theory are based on the "economy of scale". Such conceptual approaches are especially important for Georgia.

Almost every country in the world is engaged in international trade. In line with modern challenges and processes in the international division of labour, countries are in constant need to import resources and consumer products. Georgia, as a participant in the above processes, should look for ways to increase its resource potential, especially in the agri-food sector, where imports are more than three times higher than exports, and the country has many socio-economic and environmental problems [10$13]$.

As the globalization of the world economy deepens, the effectiveness of international trade is largely determined by the geographical proximity to European countries and the further development of historical and economic cooperation with them [14-15]. Based on theories of international trade, to assess the effectiveness of foreign economic relations between countries and identify current trends in the development of international trade, the current potential and future opportunities of exporting agri-food products between Georgia and the Czech Republic have been analyzed. To identify effective trade and economic potential, the key indicators of the two countries were initially evaluated (Table 1).

Table 1. Key Indicators of Georgia and the Czech Republic (based on [3]).

\begin{tabular}{|l|l|l|}
\hline & Georgia & The Czech Republic \\
\hline Area & $69,700 \mathrm{~km}^{2}$ & $78,866 \mathrm{~km}^{2}$ \\
\hline Population & 3.7 million people & 10.6 million people \\
\hline Density & 58 people $/ \mathrm{km}^{2}$ & 134 people $/ \mathrm{km}^{2}$ \\
\hline Economic Growth & $4.8 \%$ & $4.3 \%$ \\
\hline GDP Total & $\$ 15.086$ billion & $\$ 215.735$ billion \\
\hline GDP per capita & $\$ 4,046.8$ & $\$ 20,368.0$ \\
\hline $\begin{array}{l}\text { Area of agricultural land in } \\
\text { common land fund of the country }\end{array}$ & $49.0 \%$ & $55.0 \%$ \\
\hline Share of agriculture in GDP & $7.7 \%$ & $2.2 \%$ \\
\hline $\begin{array}{l}\text { Share of those employed in } \\
\text { agriculture }\end{array}$ & $47.0 \%$ & $3.0 \%$ \\
\hline Unemployment rate & $13.9 \%$ & $2.5 \%$ \\
\hline $\begin{array}{l}\text { Investment in agriculture (of total } \\
\text { investment) }\end{array}$ & $0.6 \%$ & $4.3 \%$ \\
\hline Inflation rate as of 2017 & $6.0 \%$ & $2.4 \%$ \\
\hline $\begin{array}{l}\text { Added value created in } \\
\text { agricultural business }\end{array}$ & Less than $10.0 \%$ & $2.2 \%$ \\
\hline $\begin{array}{l}\text { Expenditure on education / } \\
\text { overall European rate 5-12\% / }\end{array}$ & $2.5 \%$ & $4.0 \%$ \\
\hline
\end{tabular}

Georgia and the Czech Republic are small countries by territory, the area of the Czech Republic is only 1.1 times the size of Georgia, and its population is 2.9 times larger. Both countries are also almost identical in terms of the share of agricultural land in the total land resources: in Georgia this figure is $49 \%$, in the Czech Republic $55 \%$. The Czech Republic and Georgia show similar economic growth rates: Georgia's growth rate is $4.8 \%$, the Czech Republic's $-4.3 \%$. The opposite situation exists for the key economic indicator - gross domestic product (GDP). GDP of Georgia is 15,086 billion US dollars, of the Czech Republic - 215,735 billion US dollars. GDP per capita are 4046.8 USD and 20368 USD, respectively. Thus, the volume of GDP in the Czech Republic is 14 times, and GDP per capita is 5 times higher than in Georgia.

In the Czech Republic, the share of people employed in agriculture is quite small (3\%), but the volume of manufactured goods significantly exceeds the respective figure of Georgia. In Georgia, almost half (41.3\%) [3] of the population is employed in this sector, accounting for only $7.7 \%$ of GDP.

Indicators of investment in agriculture also differ in the two countries. If the volume of investments in agriculture in Georgia is $0.6 \%$ of the total investments, then in the Czech Republic it is $4.3 \%$.

Unlike the Czech Republic, Georgia has a high unemployment rate, but it should also be taken into account that the unemployment rate in Georgia is reduced at the expense of the self-employed people. In fact, most of the self-employed people produce the products only to meet their own needs. The latter is partially reflected in the added value created in agricultural business [17-18]. Spending on education in Georgia are also lower (2.5\%) than in the Czech Republic (4.0\%). In the Czech Republic, this indicator is close to the average European level of spending on education (5-12\%).

Thus, the comparative analysis showed that there was a similarity in quantitative indicator between Georgia and the Czech Republic, while the qualitative indicators in the Czech Republic are higher than in Georgia. By developing trade and economic relations with the Czech Republic both countries will be able to enhance e the parameters of production of local agri-food products, increase the welfare of population, and through cooperation develop better access strategies to the European markets, etc.

In Georgia, agriculture is often considered as the main source for growing the country's economy; however, the results claim the opposite [11]. The sector's share in the Georgian economy is declining in dynamics. Moreover, the sector is low-productive, overall output volume is small and growth rates are quite low. In 2004 [12], the agricultural sector of Georgia produced goods worth GEL 1.9 billion, this figure increased to GEL 4.0 billion by 2018 [3], while the average growth rate in the country remaining low. Financing of the sector has increased since 2012 , but, on the contrary, both sown area and livestock decreased. In 2017-2018, the annual decline of the sector was about 3\% (see Figure 1) [3].

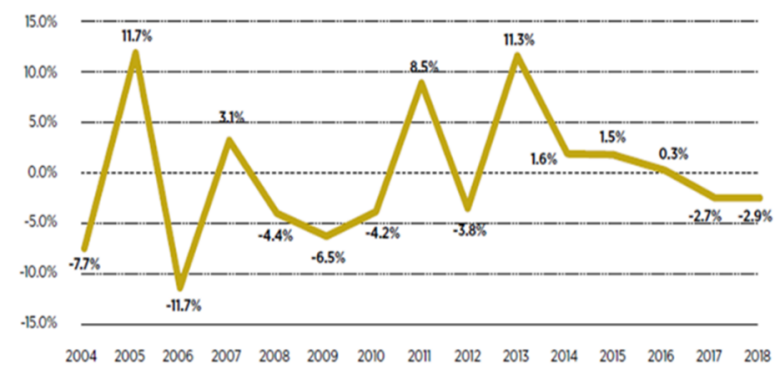

Fig. 1. Annual growth of agriculture in Georgia (\%) Source: National Statics Office of Georgia [3] 
Under these conditions, export opportunities for agrifood products are obviously limited. As of 2018, most of the exports (41\%) accounted for the CIS countries, with EU countries accounting for $28.3 \%$ [3].

The share of agri-food products in the structure of the largest export goods in Georgia is small (see figure 2) [3].

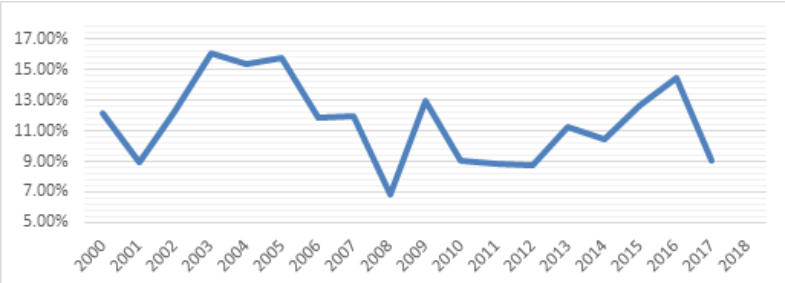

Fig. 2 .Share of agri-food products in exports in 2000-2018 (\%). Source: National Statics Office of Georgia [3]

There are only hazelnuts, wines and spirits represented in the top ten export products. Structural changes have recently been made in the export of Georgian agri-food products, in particular, in 2017, hazelnut crop was significantly damaged, and for the first time in many years it fell out of the top five export products of Georgia.

As noted, the import rate of agri-food products is significantly higher than of export and this trend remains unchanged in dynamics (see figure 3) [17].

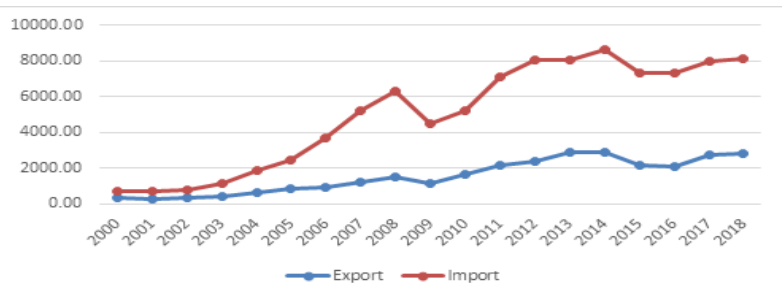

Fig. 3. Dynamics of Export and Import in Georgia in 20002018 (million US Dollars). Source: Ministry of Environmental Protection and Agriculture of Georgia

Georgia has a low level of export diversification, which is one of the main constraints in trade and economic relations between the countries. At the same time, the study of the dynamics of diversification of Georgian exports showed that it increased in 2011-2013. However, in recent years there is still a decreasing trend (see figure 4).

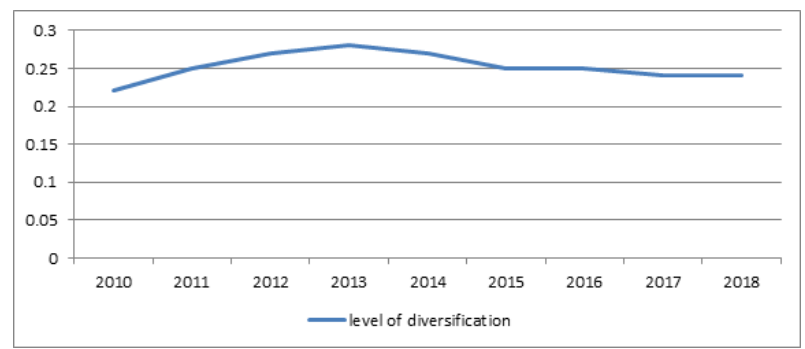

Fig. 4. Dynamics of Export and Import in Georgia in 20002018 (million US Dollars). Source: Ministry of Environmental Protection and Agriculture of Georgia [18]

An analysis of trade in agri-food products between Georgia and the Czech Republic showed that the share of agri-food products in the total exports of the Czech Republic in 2018 was $0.6 \%$. According to the data for
2019, agricultural products worth 5.4 million US dollars were exported from Georgia to the Czech Republic. This indicator increased by $55 \%$ compared to the previous year, but it is lower than in 2015 and also lower than in 2017 (see figure 5) [25].

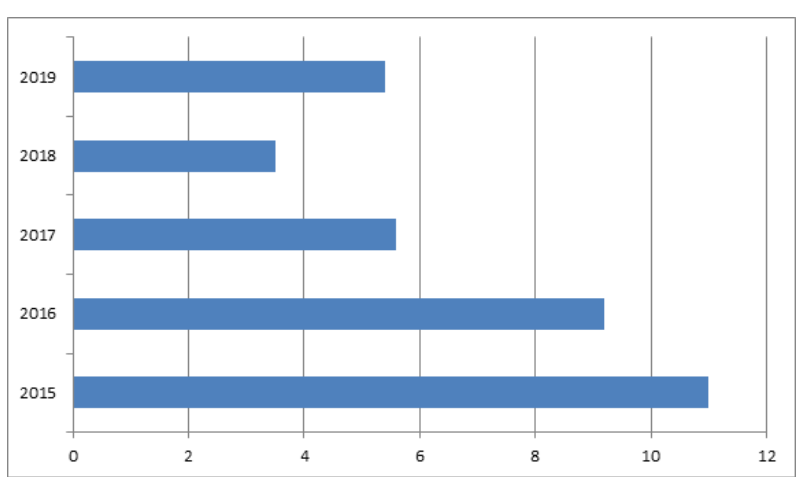

Fig. 5. Dynamics of Export of Georgian Agri-Food Products to the Czech Republic (million US Dollars). Source: Ministry of Environmental Protection and Agriculture of Georgia [18]

$89 \%$ of exported products from Georgia to the Czech Republic are hazelnuts. In 2019, the export value of this product increased by $53 \%$ compared to the previous year. Thus, the main reason for the increase in the export of agri-food products from Georgia to the Czech Republic is the increase in the export of hazelnuts. In previous years, this indicator was characterized by a downward trend. It is also worth noting that in 2019, wine, spirits, fruit jams, dried fruits, soft carbonated drinks, etc. were also exported to the Czech Republic.

In 2019, exports of alcoholic beverages increased almost six fold compared to the previous year. In the export of wine and alcoholic beverages, the trend was slightly downward; in particular, in 2019 this figure was $8 \%$ higher than in the previous year. In contrast, in 2018 , wine exports to the Czech Republic decreased by $65 \%$ compared to 2017 , while exports of alcoholic beverages decreased by $62 \%$.

In 2015-2019, import rates for agri-food products from the Czech Republic to Georgia are also of varying tendency (see figure 6).

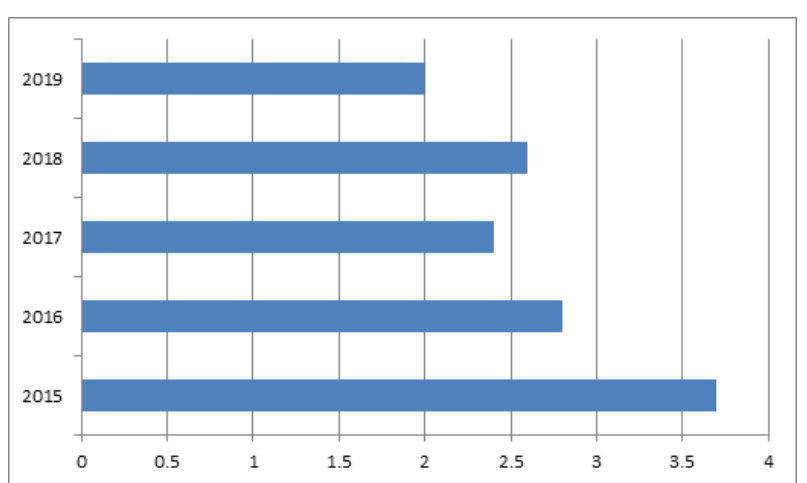

Fig. 6. Import of Czech agri-food products to Georgia [26]. Source: Ministry of Environmental Protection and Agriculture of Georgia

As of 2019, the Czech Republic accounts for $0.2 \%$ share in total agri-food imports. This year, agri-food products worth $\$ 2.0$ million have been imported from the 
Czech Republic to Georgia, which is $\$ 0.5$ million less than the previous year. In general, in 2015-2019 the import rate is characterized by a decreasing trend.

Thus, trade and economic relations between Georgia and the Czech Republic are in the process of development, and the dynamics of the export-import balance in 20122019 fluctuates (see table 2).

Table 2. Georgia's external trade with the Czech Republic in the agri-food sector.

\begin{tabular}{|l|c|c|r|r|r|r|r|r|}
\hline \multicolumn{10}{|c|}{ (thousand US Dollars) } \\
\hline & $\mathbf{2 0 1 2}$ & $\mathbf{2 0 1 3}$ & $\mathbf{2 0 1 4}$ & $\mathbf{2 0 1 5}$ & $\mathbf{2 0 1 6}$ & $\mathbf{2 0 1 7}$ & $\mathbf{2 0 1 8}$ & $\mathbf{2 0 1 9}$ \\
\hline Export & 6,804 & 9,373 & 9,986 & 11,037 & 9,217 & 5,559 & 3,483 & 5,402 \\
\hline Import & 1,808 & 2,366 & 4,652 & 3,664 & 2,799 & 2,373 & 2,580 & 2,048 \\
\hline Balance & $\mathbf{4 , 9 9 6}$ & $\mathbf{7 , 0 0 7}$ & $\mathbf{5 , 3 3 5}$ & $\mathbf{7 , 3 7 3}$ & $\mathbf{6 , 4 1 8}$ & $\mathbf{3 , 1 8 6}$ & $\mathbf{9 0 4}$ & $\mathbf{3 , 3 5 3}$ \\
\hline
\end{tabular}

Source: Compiled by the authors on an official data [3]

In 2019, the volume of export of Georgian agricultural and food products to the Czech Republic is higher compared to the previous year, but significantly lags behind the data of 2012-2016, for example, in 2012 the volume of exports amounted to 6.8 million US dollars, in 2013 - 9, 4 million US dollars, in $2014-9.98$ million US dollars, in 2015 - 11.0 million US dollars, in 2016 - 9.3 million US dollars.

The dynamics of export and import volumes vary according to the types of agri-food products. The change in export volume is shown in figure 7.

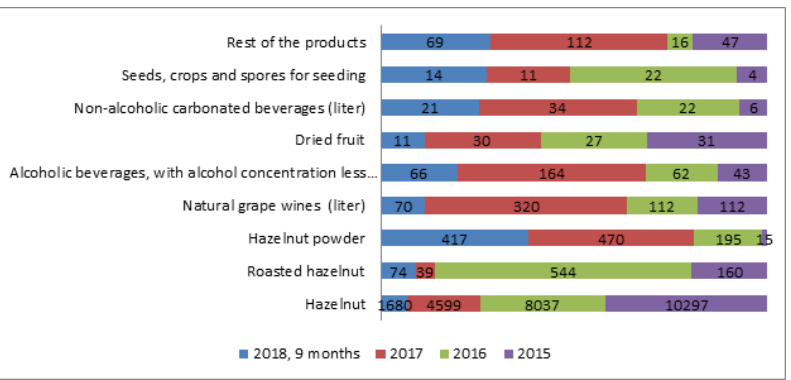

Fig. 7. Export to the Czech Republic by types of agri-food products (thousand US dollars). Source: Ministry of Environmental Protection and Agriculture of Georgia [18]

Hazelnuts predominate in the export of agri-food products (see figure 8).

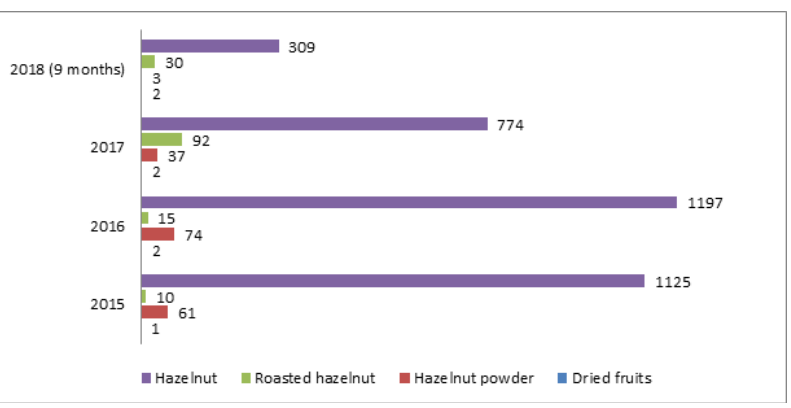

Fig. 8. Hazelnut export to the Czech Republic (tones). Source: Ministry of Environmental Protection and Agriculture of Georgia [18]

The largest share $(60 \%)$ of top 25 hazelnut export markets of Georgia falls on European countries. The Czech Republic ranks third among the top five countries
(Kazakhstan - 1,622 tonnes, Ukraine -638 tonnes, Czech Republic - 343 tonnes, Slovakia - 274 tonnes, Germany -256 tonnes) in terms of exports of hazelnut kernels from Georgia.

It should be borne in mind that the European market is characterized by high growth rates. Most of the imported hazelnut kernels in the countries of this region are processed, only a small part is sold in retail networks in the form of packages. Production costs in Europe have been rising lately, making it easier for European companies to purchase finished hazelnut products (e.g. roasted hazelnuts, skinned hazelnuts, diced hazelnuts, raw and roasted hazelnut powder and hazelnut paste) rather than importing hazelnuts directly.

In 2019, the export of hazelnuts to the Czech Republic amounted to 1238.6 tonnes, which is higher than in the previous year (688.9 tonnes in 2015, 794.0 in 2016, 931.9 in 2017, 1082.7 tonnes in 2018).

Various types of agri-food products are imported from the Czech Republic to Georgia: beer, sugar, non-alcoholic beverages, food additives, malt, etc. During the analyzed period, the volume of imports of food additives and beer decreased significantly. The volume of imports of these products to Georgia in 2019 compared to 2018 decreased by $17 \%$ and $20 \%$, respectively. In addition, the volume of sugar imports in 2018 amounted to 132000 US dollars, in 2016 - 1.1 million US dollars, and in 2019 sugar was not imported from the Czech Republic. Such a sharp decline in sugar import is the main reason for the decline in the value of imported agri-food products from the Czech Republic. Over the same period, imports of malt and nonalcoholic carbonated beverages increased, in particular, in 2019, compared to the previous year, the volume of imports of malt increased by $36 \%$, and of non-alcoholic carbonated beverages -12 times.

As of 2019, agri-food products worth 2.0 million USD are imported from the Czech Republic to Georgia, which is 0.2 million USD higher than in 2012, although lower by 2.6 million USD compared to 2014 (the highest volume of imports was recorded this year -4.6 million dollars). An analysis of 2013-2016 showed that the volume of imports over this period showed a downward trend.

Different types of agri-food products are imported from the Czech Republic to Georgia (see figure 9, figure 10).

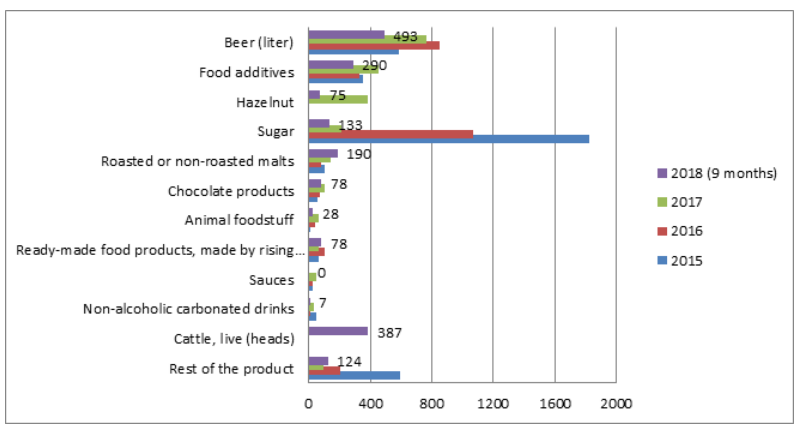

Fig. 9. Import from the Czech Republic by product types (thousand US dollars). Source: Ministry of Environmental Protection and Agriculture of Georgia [18] 


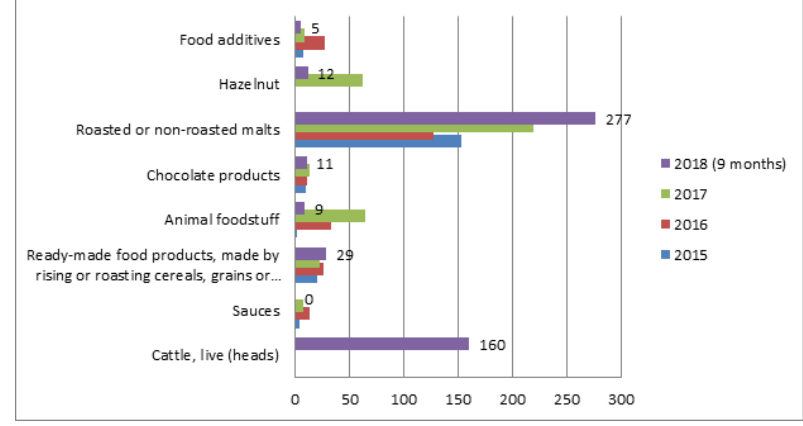

Fig. 10. Import from the Czech Republic by product types (thousand US dollars). Source: Ministry of Environmental Protection and Agriculture of Georgia [18]

\section{Conclusion}

Thus, the Czech Republic is one of the important partners of Georgia in terms of trade and economic relations. The doubling of relations between Georgia and the Czech Republic is actively discussed at the government level in Georgia. In this regard, Georgia's cooperation with the Czech Republic is promising not only in trade, but also in investment and modern technology. It is also important to diversify the export-import of agri-food products between the Czech Republic and Georgia, on the one hand, and transfer Czech production and modern technology to Georgia.

Trade and economic relations between Georgia and the Czech Republic are in the process of development. It is expected that the assessments of the development trends of export and import of agri-food products will bring the economic ties between the countries to a qualitatively new level in the future.

The markets of European countries, including the market of the Czech Republic, have been characterized by high growth rates in recent years. However, these markets are highly sensitive to price and quality. Prices formed on Georgian agri-food products will have a significant impact on export growth. In view of the above, it is necessary to study the factors affecting the value chain of agricultural products, as well as the pricing mechanism.

The main food products exported from Georgia to the Czech Republic is hazelnut. Given the fact that the confectionery industry began to replace this ingredient with cheaper hazelnuts and raw materials, as well as processed products found in new export markets, it will be necessary to set the direction of formation and improvement of the effective value chain of nuts. However, food safety requirements are high in European countries that exporters of agri-food products, including the hazelnut exporters, must consider [19-22].

Types of products are limited in the volume of exports and imports of agri-food products between Georgia and the Czech Republic. For the further development of trade and economic relations, diversification of export and import products will be required.

The characteristics and changes of globalization in trade and economic relations require the development of appropriate government policies. It is extremely important to determine the direction of stimulating economic competitiveness and increasing added value in the country.

In the future, trade and economic relations between Georgia and the Czech Republic are expected to double. In such circumstances, cooperation with the Czech Republic will be promising for Georgia both in the field of trade, and in the field of investment and the use of modern technologies. In the short term, it will be necessary to diversify the export-import of agri-food products between the Czech Republic and Georgia and begin the process of transferring Czech production and / or modern technologies to Georgia.

- Currently, the data on export statistics of Georgia's foreign trade are incomplete, which creates significant obstacles to the assessment of trade and economic processes between countries and hinders effective cooperation. Adjustment of the database of prices for export-import goods will create a reliable information base for calculating foreign trade indices, facilitate the implementation of foreign trade and bring it into line with international standards.

\section{References}

1. T. Bidzinashvili, Ways to increase the export potential of Georgia in the context of globalization of world trade relations (Tbilisi, 2016)

2. E. Kharaishvili, Challenges for sustainable food security in Georgia. XV EAAE Congress in Parma: Towards Sustainable Agri-Food Systems: Balancing between Markets and Society (Parma, 2017)

3. National Statistics Office of Georgia: Regional Development (2020), https://www.geostat.ge/en

4. A. Smith, An Inquiry Into the Nature and Causes of the Wealth of Nations (Tbilisi, 1938)

5. D. Ricardo, On the Principles of Political Economy and Taxation (Bell and sons, 1891)

6. N. C. Pahariya, Import Substitution and Export Promotion as Development Strategies (Briefing Paper TDP, 2008)

7. S. Neumann, Import Substitution Industrialization and Its Conditionalities for Economic Development a Comparative analysis of Brazil and South Korea (Central European University, 2013)

8. E. Kharaishvili, I. Natsvlishvili, Georgian Agri-Food Markets and Export-Stimulating Economic Policy, Globalization and Business 8, 44-53 (2019)

9. P. H. Lindert, International Economics (Tbilisi: News, 2009)

10. I.W.E.Arsawan, V.Koval, I. Rajiani, N.W. Rustiarini, W.G. Supartha, N.P.S. Suryantini, Leveraging knowledge sharing and innovation culture into SMEs sustainable competitive advantage. International Journal of Productivity and Performance Management, (2020 in press) https://doi.org/10.1108/IJPPM-04-2020-0192

11. N. Shmygol, F. Schiavone, O. Trokhymets, D. Pawliszczy, V. Koval, R. Zavgorodniy, A. Vorfolomeiev, Model for assessing and 
implementing resource-efficient strategy of industry. CEUR Workshop Proceedings 2713, 277-294 (2020)

12. B. Namchavadze, Why is agriculture not developing? (Forbes, 2018), https://forbes.ge

13. E. Kharaishvili, B. Gechbaia and G. Mamuladze, Vegetable market: Competitive advantages of Georgian product and competition challenges, Innovative Marketing 14, 8-16 (2018).

14. K. Kostetska, N. Khumarova, Umanska, Y., N. Shmygol, V. Koval, Institutional qualities of inclusive environmental management in sustainable economic development. Management Systems in Production Engineering 28 (2), 15-22 (2020)

15. M. Jibuti, Administrative Division, Regions of Georgia and their Characteristics. Globalization And Business 8, 126-129 (2019)

16. V. Koval, N. Kovshun, O.Plekhanova, S. Kvitka, O. Haran, The role of interactive marketing in agricultural investment attraction. SGEM 19(5.3), 877-884 (2019).

17. V. Koval, I. Mikhno, O. Trokhymets, L. Kustrich, N.Vdovenko, Modeling the interaction between environment and the economy considering the impact on ecosystem. E3S Web Conf. 166, 13002 (2020)

18. Ministry of Environmental Protection and Agriculture of Georgia. The chart is based on data from the Ministry of Environmental Protection and Agriculture of Georgia (2019), https://mepa.gov.ge/En/.

19. E. Kharaishvili, Wine Market and Competitive Models of Viticulture and Winemaking Diversification in Georgia (Tbilisi, 2017)

20. B. Notarnicola, K. Hayashi, M. A. Curran, D. Huisingh, Progress in working towards a more sustainable agri-food industry. Journal of Cleaner Production 28, 1-8. (2012)

21. W. M. Jongen, M. T. G. Meulenberg, Innovation in agri-food systems (Wageningen Academic Publishers, 2005)

22. R. Sarker, S.Jayasinghe, Regional trade agreements and trade in agri-food products: evidence for the European Union from gravity modeling using disaggregated data. Agricultural Economics 37(1), 93-104 (2007) 